\title{
PARTICULATE MATTER IN ATMOSPHERIC AIR IN URBAN AGGLOMERATION
}

\author{
Halina Marczak \\ 1 Institute of Transport, Internal Combustion Engines and Ecology, Lublin University of Technology, \\ Nadbystrzycka 36, 20-618 Lublin, Poland, e-mail: h.marczak@pollub.pl
}

Received: 2017.01.25

Accepted: 2017.03.07 Published: 2017.05.02

\begin{abstract}
The study aimed to determine the mass concentration of PM10 in the air in urban area. The specific objective of the research was to analyze and assess the impact of transport road emissions on the level of concentration of particulate matter in the atmosphere in the Lublin agglomeration. The measuring points were located in places at different distances from the communications emission sources and, at the same time, possibly varying degrees of air pollution dust. Measuring the concentration of dust at the measuring points was performed using an indirect method using a laser photometer. In the research point which was not under direct influence of a heavy traffic road dust levels lower by $10.5 \%$ to $65.4 \%$ than in the vicinity of the transport route were reported. Small particle air pollution at all the points covered by the study increased significantly during the heating season. Based on the comparison of the obtained values of PM10 concentrations with legal standards, it was found that the air pollution exceeded the limits in all measurement points only during a series of measurements in the months of November-December. The recorded increase in air pollution during the heating season should be associated with an increased dust emissions in this period from the "low" emitters - local house boilers and detached houses.
\end{abstract}

Keywords: particulate matter, PM10, dust emissions, dust emissions from road transport

\section{INTRODUCTION}

Particulate matter in the air is a mixture of small solid particles and liquids. Its content in the air is the result of a balance between dust emission and the amount of dust removed from the air. Fractional composition and chemical dust emitted into the air depends on the specific sources of emissions. Moreover, the chemical composition of dust in the air is influenced by the coexisting pollutants, and the products of their transformations in the air - because the dust is a surface adsorption for them. The products of chemical reactions involving e.g., sulphur oxides, nitrogen and ammonia are sulfate, nitrate, and ammonium ions, which can retain dust particles on the surface. Chemical analyzes of dust also show the presence of the heavy metals and hydrocarbons. Specific threat to air quality and human health is the fine fraction of particulate matter with an aerodynam- ic diameter of grains to $2.5 \mu \mathrm{m}$ (PM2.5) due to the possibility of entering lungs and the bloodstream [Fudała J. 2013]. Permissible level of PM2.5 is 25 $\mu \mathrm{g} / \mathrm{m}^{3}$ for one year average [Regulation ... 2012].

In shaping the air quality in Poland combustion of fossil fuels in the residential sector and road transport are important anthropogenic sources. Emissions of dust (as total particulate matter) in Poland in 2013 amounted to 407.36 thousand tons, including 35,89 thousand ton from combustion in the sector of energy production and transformation, 32.12 thousand ton from combustion in the industry, 163.64 thousand ton from combustion outside the industry (including 129.64 thousand tons in households), 34.12 thousand ton from production processes, 20.13 thousand ton from waste processing, [GUS Environment 2015]. The share of dust emissions from the road transport in particulate emissions in Poland in 2013 was approx. 75.88 thousand ton [GUS 
Freight 2015]. Road transport is also a source of secondary dust emissions resulting from raising particulates from contaminated road surfaces by moving vehicles. Road transport plays an important role in shaping the quality of the environment in the cities and in the vicinity of roads with heavy traffic.

\section{DUST EMISSION IN ROAD TRANSPORT}

Dust emissions in road transport is the sum of emissions from internal combustion engines of vehicles, emissions from wearing tires, brake linings and road surfaces and secondary emissions resulting from raising solid particles from the road surfaces by moving cars.

Emissions of particulate matter from road transport in Poland in 2013 was 75.88 thousand ton and consisted of emissions of particulate matter from the exhaust gases, amounting to 17.09 thousand ton and dust emissions from wear of tires, brakes and road surfaces with a value of 58.77 thousand ton. The share of particulate matter from exhaust gases in emissions are [GUS Freight 2015]:

- Passenger cars, generating 7.43 thousand ton of dust,

- Trucks with a weight up to $3500 \mathrm{~kg}$ emitting 2.49 thousand ton of dust,

- Trucks with a weight exceeding $3500 \mathrm{~kg}$, buses and tractors emitting 7.17 thousand ton of dust.

Secondary emission of PM10 from the road surface is up to $60 \%$ of total emission of dust from road transport. It depends on, among others, on the type and the technical conditions of the road surface, speed of travel, vehicle weight and roadsides development [Chmura U. et al. 2011]. Secondary emissions of dust from paved roads can be determined based on empirical equation developed by the US EPA (United States Environmental Protection Agency) [EPA, 2011]:

$$
E=k(s L)^{0,91} W^{1,02}
$$

where: $E$ - emission of dust, g/VKT (VKT - Vehicle Kilometer Traveled)

$k$ - grain size coefficient $(\mathrm{k}=0.62 \mathrm{~g} / \mathrm{VKT}$ for PM10; $\mathrm{k}=0.15 \mathrm{~g} / \mathrm{VKT}$ for PM2.5, $\mathrm{k}$ $=0.77 \mathrm{~g} / \mathrm{VKT}$ for PM15, $\mathrm{k}=3.23 \mathrm{~g} / \mathrm{VKT}$ for PM30)

$s L$ - load dust of road, $\mathrm{g} / \mathrm{m}^{2}$

$W$ - average weight of vehicles on the road, $\mathrm{Mg}$.
Equation (1) is used for the parameter ranges:

- load dust of road (sL): $0.03-400 \mathrm{~g} / \mathrm{m}^{2}$

- average weight of the vehicle (W) on the road: $1.8-38 \mathrm{Mg}$

- average speed of vehicles on the road: $1-88$ $\mathrm{km} / \mathrm{h}$.

According to data contained in the materials of the European Environment Agency (EEA) [EEA 2007] particulate matter in the car exhaust gas consists of $100 \%$ of PM2.5. This means that the emission of exhaust particulate matter with an aerodynamic diameter of $10 \mu \mathrm{m}$ (PM10) is equal to the emissions of PM2.5. Grain classes of dust from wearing tires, brake elements and the road surface are shown in Table 1 [EEA 2013].

\section{RESEARCH OBJECTIVE, SUBJECT AND METHODOLOGY}

The aim of the study was to analyze the concentration of dust in the atmosphere in the urban area. The subject of research was atmospheric air in the city of Lublin. The measuring points were located in places that are at different distances from the communications sources of emission and, at the same time, possibly varying degrees of air pollution dust. Three measuring points were located in the center of the city, and the fourth measuring point on the southern border of the city (Fig. 1):

- Measuring point 1 (PP1) - next to the intersection of Zana-Nadbystrzycka with heavy traffic.

- Measuring point 2 (PP2) - near the intersection of Pilsudski-Narutowicz-Lipowa with severe car traffic.

- Measuring point 3 (PP3) - situated in the green areas of Lublin University of Technology (PL) outside the direct influence of linear

Table 1. Fractional composition of particulate matter from wear of tires, brake components and roads [European Environmental Agency in 2013]

\begin{tabular}{|l|c|c|c|}
\hline \multirow{2}{*}{ Dust fraction } & \multicolumn{3}{|c|}{ Mass share in particulate matter from the } \\
\cline { 2 - 4 } & tires & brakes & road surface \\
\hline $\begin{array}{l}\text { Particulate } \\
\text { matter total }\end{array}$ & 1.00 & 1.0 & 1.0 \\
\hline PM10 & 0.6 & 0.98 & 0.5 \\
\hline PM2.5 & 0.42 & 0.39 & 0.27 \\
\hline PM1 & 0.06 & 0.1 & - \\
\hline PM0.1 & 0.048 & 0.08 & - \\
\hline
\end{tabular}




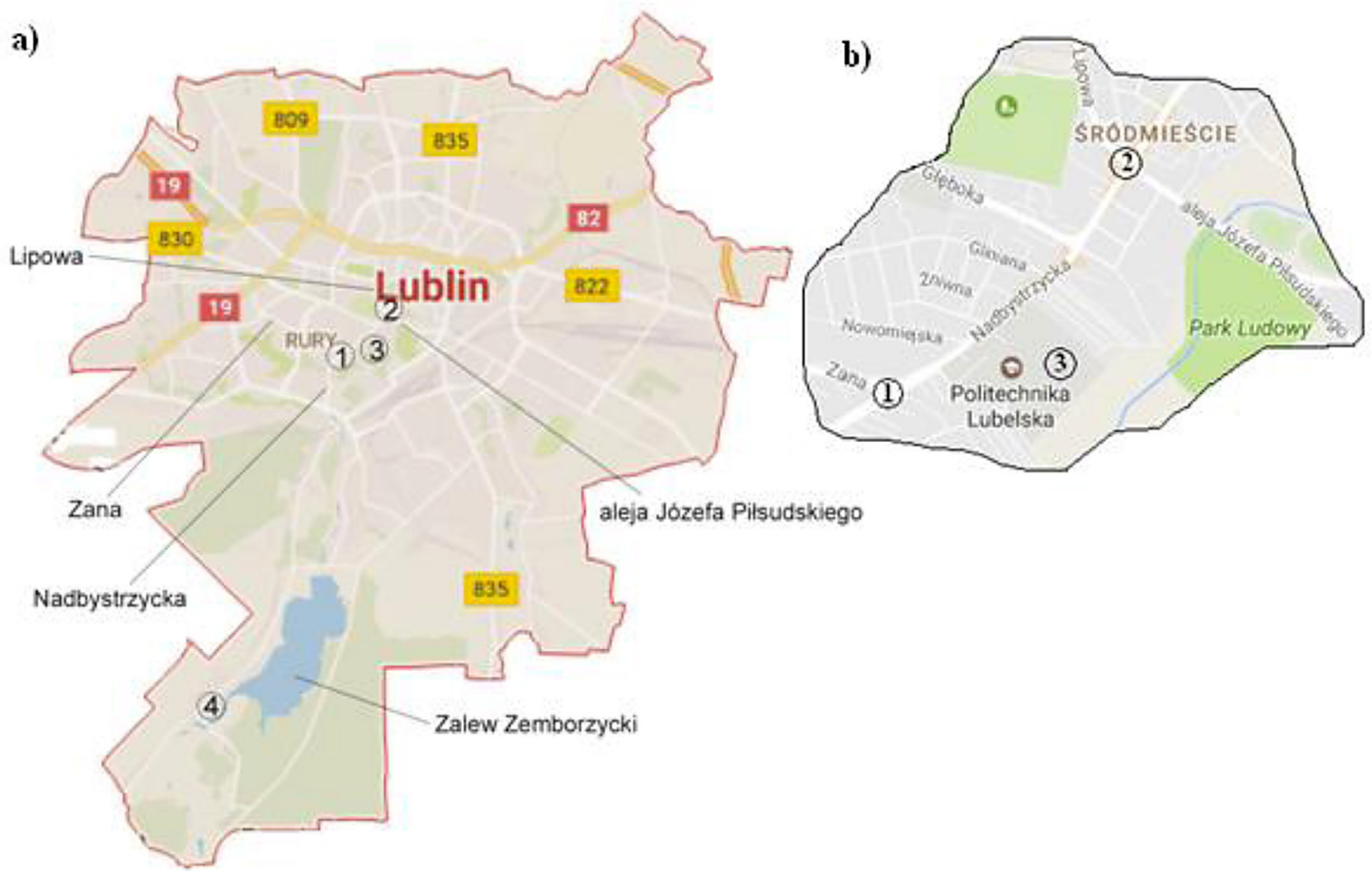

Figure 1. Location of measurement points: a) against the city plan, b) in a magnified portion of the city plan

communication sources. Green areas of PL are a place of recreation and leisure for students.

- Measuring point 4 (PP4) - located in an attractive recreational area in the vicinity of Zemborzyce, which is the edge of Zemborzycki Lagoon located in the basin of the Bystrzyca river.

Measuring the concentration of dust in the measuring points was performed using the indirect method of measurement using the DustTrak DRX Aerosol Monitor meter model 8533 (TSI Inc.). Precision measuring device allows for a short time sampling of the tested gas and allows the determination of the mass concentration of particulate matter having a particle size range of $0.1-15 \mu \mathrm{m}$. It is a portable laser photometer which measures the concentration of dust in real time, based on the attenuation of laser light scattered from the sample at an angle of $90^{\circ}$. A single measurement lasted $5 \mathrm{~min}$. The tested air passed through the meter at a constant flow rate $(3 \mathrm{l}$ / $\mathrm{min})$. Averaging period was 30 seconds. The averaged measurements were collected automatically and stored in the output file in the memory of the meter. For measuring a duration of $5 \mathrm{~min}$, and the frequency of recording the results of 30 sec, a stream of 10 results for the concentrations of particulate matter was obtained. The study was conducted during the months of late spring
(May - June) and in autumn and winter months (October - December). At measuring points 1-3 six independent series of measurements were carried out, each consisting of two successive measurements. Measurements of dust concentration at the measuring points 1-3 were performed on the same day between $2.00 \mathrm{p} . \mathrm{m}$. and $4.00 \mathrm{p} . \mathrm{m}$. At the measuring point 4 two series of measurement were made - in June and in November. During the test the concentration of dust at the measuring points $1-4$ also the temperature was measured, humidity and air movement using a digital probe - thermoaneometer Mastech MS6252B.

\section{TEST RESULTS}

The results of measurements of the concentration of dust in the air in the test points are shown in Figures 2-5. At the measuring point 1 located in Zana St. with high-traffic communications the average PM10 concentration level of $0.019 \mathrm{mg} /$ $\mathrm{m}^{3}$ (Series II) to $0.281 \mathrm{mg} / \mathrm{m}^{3}$ (Series VI) was reported (Fig. 2). In the PP2 location, which was located in the immediate vicinity of streets with heavy traffic, the average PM10 concentration ranged from $0.023 \mathrm{mg} / \mathrm{m}^{3}$ (I series) to $0.3925 \mathrm{mg} /$ $\mathrm{m}^{3}$ (Series VI) (Fig. 3). In the measuring points 


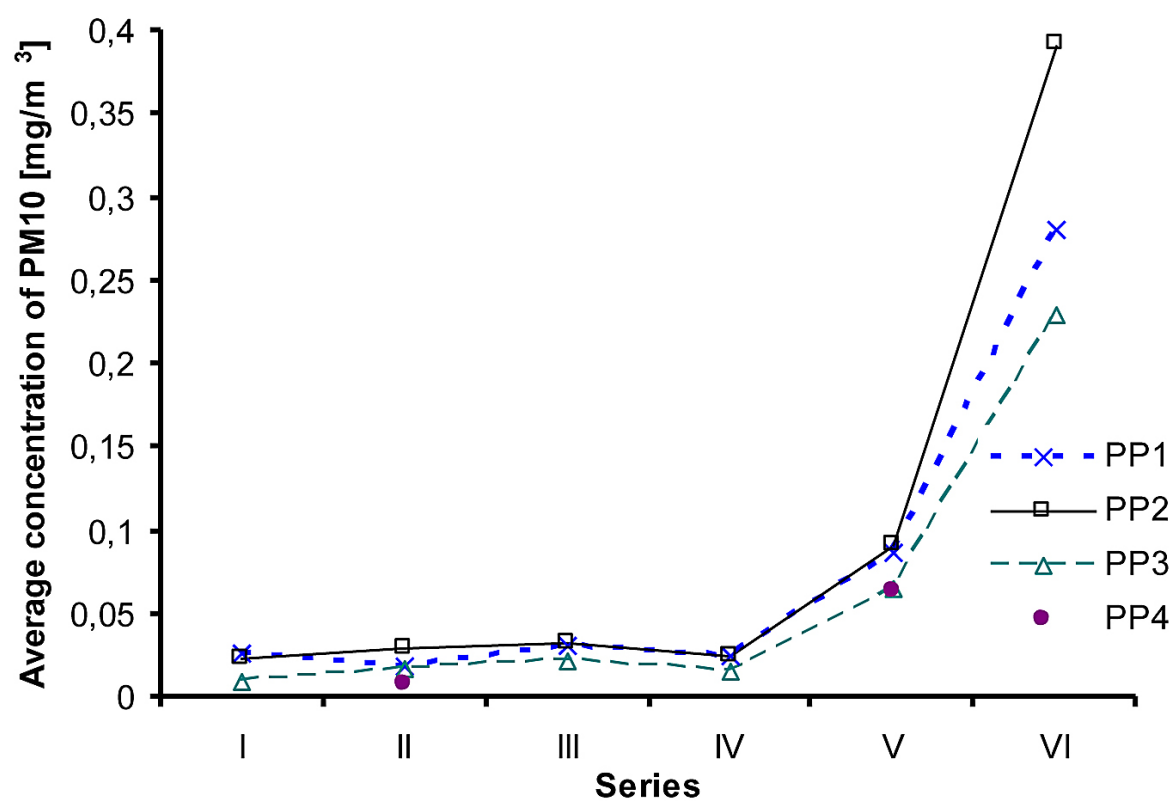

Figure 2. The results of measurements of mass concentrations of PM10 in ambient air in measuring series

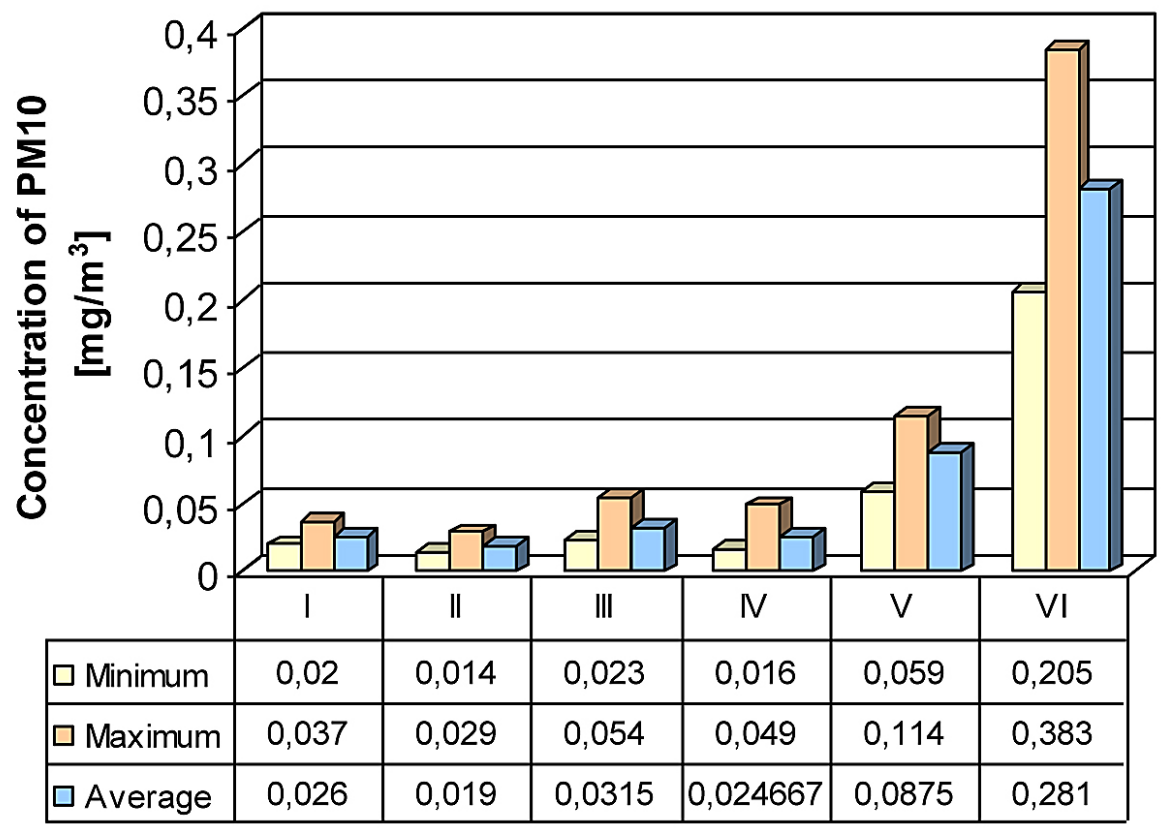

Figure 3. Results of measurements of dust concentrations in PP1

1 and 2 the expected similar level of air pollution with particulate matter was recorded. It was related to the fact that in these places the sampled air quality was affected by the same sources of emissions. These are mainly the transport emissions and in the heating season the combustion of fuels in a power plant (CHP Lublin Wrotków), municipal heating plants and in households.

Measuring points PP1 and PP2 were slightly different because of land development in their neighborhood. Intersection of Zana-Nadbystrzyc- ka (PP1) is more extensive and surrounded by scattered buildings of different heights, in contrast to the lower intersection of Pilsudski-Narutowicz-Lipowa (PP2), surrounded by a compact, dense, mainly high building development.

Measuring point 3 located in the green areas of Lublin University of Technology, approx. $200 \mathrm{~m}$ (in a straight line) from an important communication route in Nadbystrzycka street. The landscape is dominated by green grass and trees. In the PP3 location in series from I to VI the lowest concen- 


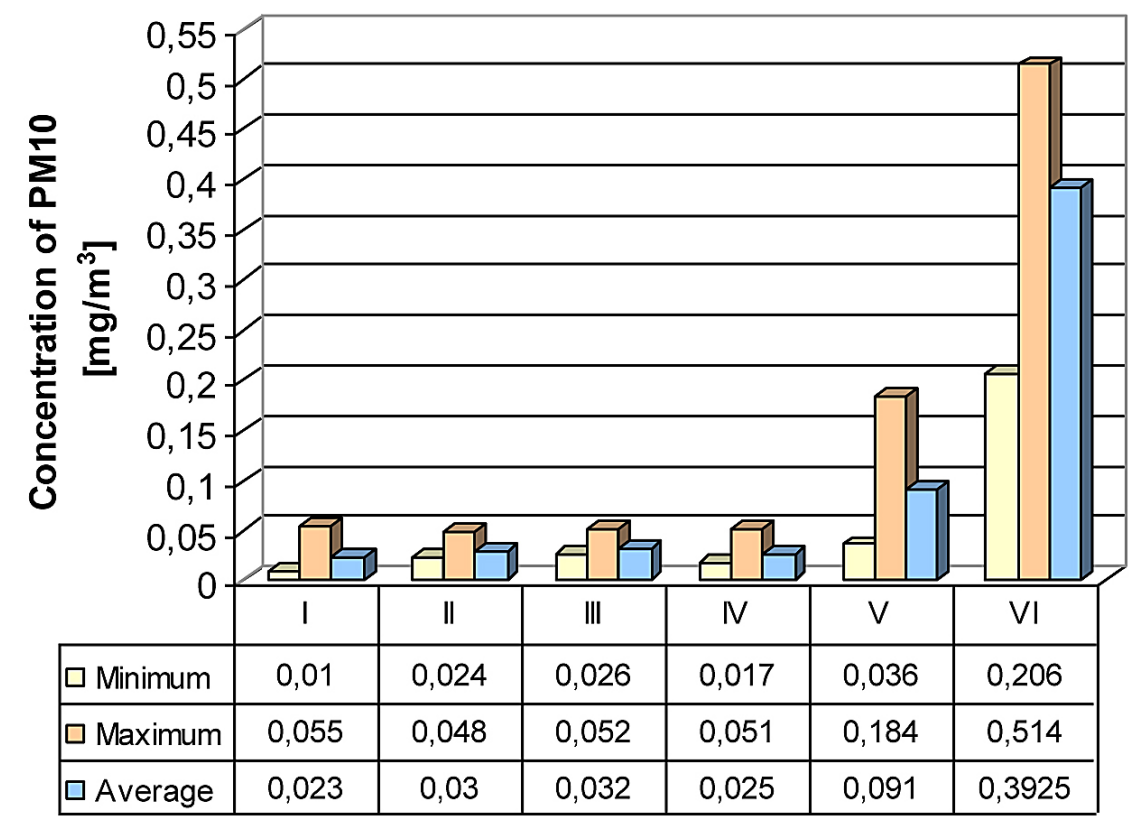

Figure 4. Results of measurements of dust concentrations in PP2

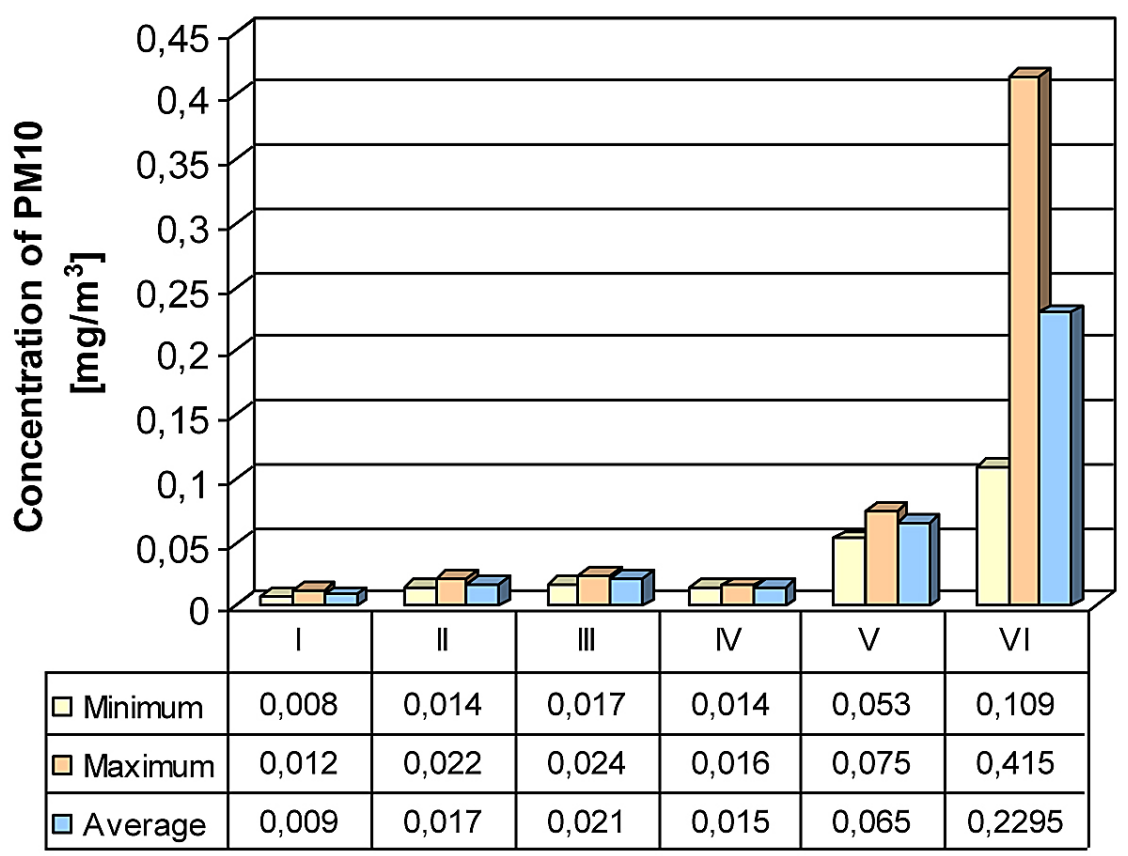

Figure 5. Results of measurements of dust concentrations in PP3

trations of PM10 were recorded in comparison to the results of the measuring points 1 and 2. They are shaped at a level of $0.009 \mathrm{mg} / \mathrm{m}^{3}$ (series I) to $0.229 \mathrm{mg} / \mathrm{m}^{3}$ (Series VI). Dust in the air in the research site which is away from a busy street (PP3) increased significantly during the heating season. Fuel combustion processes in the local boiler and household furnaces had a particular impact on the amount of pollutants in the air (including dust) in this period.
It should be emphasized that in winter in series VI during the heating season the highest values of PM10 in each of the three sites (PP1-PP3) were recorded.

At the measuring point 4 , located in the vicinity of Zemborzycki Lagoon in June concentrations of PM10 value of $0.007 \mathrm{mg} / \mathrm{m}^{3}$ were recorded. This result was the lowest of all the analyzed areas. Preferably, the air quality in the area was affected by the lack of direct communication 
emissions. Fuel combustion processes in housing for heating purposes contribute to an increase in the concentration of dust, observed on the basis of measurement in November.

Table 2 shows the values of temperature, relative humidity and flow rate of air during sampling. The highest values of PM10, regardless of temperature and humidity, was observed in the vicinity of arterial roads. The conditions of high relative humidity (series V and VI at the measuring points PP1-PP3) yielded high levels of dust concentration. In order to minimize the effect of humidity on the results, the measurements should be repeated with a probe which includes a conditioning air circuit (heated air inlet). Increased concentrations of PM10 measured in this way during the heating season could be attributed to emissions from local sources of heat.

According to the Regulation of the Minister of Environment of 24 August 2012. [... Regulation 2012], acceptable level of PM10 in the air is for the time averaging 24 hours $50 \mu \mathrm{g} / \mathrm{m}^{3}$, and for the calendar year $40 \mu \mathrm{g} / \mathrm{m}^{3}$. The comparison of the results of concentrations of PM10 with limit values can give a conclusion that the dust of air was higher than the permissive standards in all measurement points only during testing in November (PP4) and December (PP1-PP3). These are the months of the heating season, in which increased air dustiness is affected by particulate emissions from "low" emitters - chimneys and local household boilers in houses.

In summary, the results of the measurements confirmed the expected higher levels of PM10 in the neighboring streets with heavy traffic. Recreational areas (green areas of university) reported lower levels of dust in Series II by $10.5 \%$, and in Series I - lower by $65.4 \%$ than PM10 concentration in the vicinity of the intersection ZanaNadbystrzycka (PP1). A comparison of the concentrations in the measurement point 2 (not far from the intersection of Pilsudski-NarutowiczLipowa) and 3 (green areas of university) shows that the concentration of PM10 in the designated measuring point 3 accounted for $39.1 \%$ (series I) to $71.4 \%$ (series V) of the values of PM10 in the denoted point PP2. Based on the measurement results, it was found that during the heating season increased concentration of PM10 at the measuring points was recorded.

\section{CONCLUSIONS}

Research on particulate matter of PM10 in the Lublin agglomeration using the Dust Trak instrument showed that increased traffic has an impact on the concentration of particulate matter in the atmosphere. Near the junction of the busy urban roads, PM10 was higher than in the area away

Table 2. The values of temperature, relative humidity and air flow rate during measurements

\begin{tabular}{|c|c|c|c|c|c|}
\hline Measurement point & Series (date) & $\begin{array}{c}\text { Probe altitude } \\
\text { (above the ground) } \\
{[\mathrm{m}]}\end{array}$ & $\begin{array}{c}\text { Temperature } \\
{\left[{ }^{\circ} \mathrm{C}\right]}\end{array}$ & $\begin{array}{l}\text { Relative humidity } \\
{[\%]}\end{array}$ & $\begin{array}{c}\text { Air flow speed } \\
{[\mathrm{m} / \mathrm{s}]}\end{array}$ \\
\hline \multirow{6}{*}{ PP1 } & $\mathrm{I}(16 / 05 / 2016)$ & \multirow{6}{*}{1.2} & 16.2 & $38.7-39.5$ & $1.0-1.5$ \\
\hline & II (03/06/2016) & & 26.2 & $36.7-37.2$ & $0.36-2.2$ \\
\hline & III (17/06/2016) & & 29.3 & 46.2 & $1.2-2.4$ \\
\hline & IV (07/10/2016) & & 13.6 & 43.7 & $0.05-1.5$ \\
\hline & $\mathrm{V}(19 / 12 / 2016)$ & & $2.2-2.8$ & $82.5-85.5$ & $0.75-2.79$ \\
\hline & $\mathrm{VI}(22 / 12 / 2016)$ & & $0.7-1.0$ & 78.0 & $0.5-1.3$ \\
\hline \multirow{6}{*}{ PP2 } & $\mathrm{I}(16 / 05 / 2016)$ & \multirow{6}{*}{1.2} & 16.7 & 39.7 & $0.8-1.3$ \\
\hline & II (03/06/2016) & & 26.5 & $36.5-37.7$ & $1.0-1.5$ \\
\hline & III (17/06/2016) & & 29.5 & 46.3 & $0.9-2.2$ \\
\hline & IV (07/10/2016) & & 14.0 & 43.8 & $0.05-1.3$ \\
\hline & $\mathrm{V}(19 / 12 / 2016)$ & & 2.5 & $79.5-80.5$ & $0.23-1.9$ \\
\hline & $\mathrm{VI}(22 / 12 / 2016)$ & & 2.5 & 74.0 & $0.3-0.65$ \\
\hline \multirow{6}{*}{ PP3 } & $\mathrm{I}(16 / 05 / 2016)$ & \multirow{6}{*}{1.2} & $12.8-13.5$ & $47.7-48.2$ & $1.35-2.86$ \\
\hline & II (03/06/2016) & & 26.2 & $36.7-37.2$ & $0.36-2.2$ \\
\hline & III (17/06/2016) & & 29.3 & 46.2 & $1.2-2.4$ \\
\hline & IV $(07 / 10 / 2016)$ & & 13.6 & 43.7 & $0.05-1.5$ \\
\hline & $\mathrm{V}(19 / 12 / 2016)$ & & $2.2-2.8$ & $82.5-85.5$ & $0.75-2.79$ \\
\hline & $\mathrm{VI}(22 / 12 / 2016)$ & & $0.5-1.0$ & $80.0-82.0$ & $0.16-2.35$ \\
\hline \multirow{2}{*}{ PP4 } & $(05 / 06 / 2016)$ & \multirow{2}{*}{1.2} & 23.5 & 32.2 & $1.5-2.7$ \\
\hline & $(20 / 11 / 2016)$ & & 8.5 & 65.5 & $1.2-2.5$ \\
\hline
\end{tabular}


from those routes (PP3). The smallest dustiness was found at the measurement point (PP4) in the recreation center on the outskirts of the city.

During the months of the heating season higher concentrations of PM10 were recorded in the measuring points, in comparison to the results of a series of measurements made at these points before the beginning of the heating period. The highest levels of dust concentrations were found in conditions of high relative humidity (series $\mathrm{V}$ and VI at the measuring points 1-3).

To minimize the effect of humidity on the results of the research further tests should be carried with a probe equipped with an air conditioning inlet (heated air inlet). The increased PM10 concentrations could be then explained by emissions from local sources of heat.

\section{REFERENCES}

1. Chmura U. et al. 2011. Report for the city of Kielce on. Inventory of sources of emissions into the air due to the need to update databases on the condition and air protection, among others, for the integration of systems for collecting and processing data on the environment in the Municipal Spatial Information System. Atmoterm SA

2. European Environmental Agency (EEA) 2007. Technical Report B710. EMEP/CORINAIR Emission Inventory Guidebook - 2007. Group 7: Road Transport.

3. European Environmental Agency (EEA) 2013. Technical Report. EMEP/EEA air pollutant emission inventory guidebook - 2013. Technical guidance to prepare national emission inventories. Doi: $10.2800 / 92722$.

4. Environmental Protection Agency (EPA) 2011. Compilation of Air Pollutant Emission Factors AP - 42, 5. Edition, Vol. 1: Stationary Point and Area Sources. Chapter 13.2.1: Paved Roads.

5. Fudała J. 2013. Metale ciężkie w powietrzu atmosferycznym. Ekorozmowy. Zielona Liga.

6. GUS, Urząd Statystyczny w Szczecinie, Departament Handlu i Usług 2015. Transport drogowy w Polsce w latach 2012 i 2013. Zakład Wydawnictw Statystycznych, Warszawa.

7. GUS, Departament Badań Regionalnych i Środowiska 2015. Ochrona środowiska 2015. Zakład Wydawnictw Statystycznych, Warszawa.

8. Rozporządzenie Ministra Środowiska z dnia 24 sierpnia 2012 r. w sprawie poziomów niektórych substancji w powietrzu. Dz.U. 2012 poz. 1031. 